\title{
Periphytic diatoms (Bacillariophyta) in streams from three Conservation Units of central Brazil: Pinnularia Ehrenberg ${ }^{1}$
}

\author{
Alline Alves França ${ }^{2}$, Bárbara Dunck ${ }^{3,6}$, Liliana Rodrigues ${ }^{4}$, Bárbara Medeiros Fonseca $^{5}$ and \\ Sirlene Aparecida Felisberto ${ }^{2}$
}

Received: 12.12.2016; accepted: 9.07.2017

\begin{abstract}
Periphytic diatoms (Bacillariophyta) in streams from three Conservation Units of central Brazil: Pinnularia Ehrenberg). This study aimed to survey the genus Pinnularia Ehrenberg (Bacillariophyta) in five preserved streams located in three conservation units (Brasília National Park, Chapada dos Veadeiros National Park and Terra Ronca State Park). Periphyton was collected in different substrata during the dry and rainy seasons (years 2012 to 2013), totalizing 25 sample units. Altogether, 23 taxa were identified, being P. subanglica, P. angustivalva and P. butantanum the most frequent. Pebble and sand were the richest substrates, with nine taxa each. Among the 23 taxa reported, 13 are cited for the first time for the central Brazil: P. angusta var. angusta, $P$. angustivalva, $P$. butantanum, $P$. divergens var. biconstricta, $P$. divergens var. mesoleptiformis, $P$. gibba var. subundulata, P. paulensis, $P$. persudetica var. persudetica, $P$. subgibba var. angustarea, $P$. subgibba var. capitada, . superpaulensis, $P$. viridiformis var. minor and $P$. undula var. undula.
\end{abstract}

Keywords: biodiversity, Cerrado, diatom, periphyton, pristine lotic systems

RESUMO - (Diatomáceas perifíticas (Bacillariophyta) em riachos de três Unidades de Conservação do Brasil Central: Pinnularia Ehrenberg). Este estudo objetivou inventariar o gênero Pinnularia Ehrenberg (Bacillariophyta) em cinco riachos preservados localizados em três unidades de conservação (Parque Nacional de Brasília, Parque Nacional da Chapada dos Veadeiros e Parque Estadual de Terra Ronca). O perifíton foi coletado em diferentes substratos durante estações secas e chuvosas (anos de 2012 e 2013), totalizando 25 unidades amostrais. Ao todo 23 táxons foram identificados, sendo $P$. subanglica, $P$. Angustivalva e $P$. butantanum as mais frequentes. Seixos e silte foram os substratos mais ricos em espécies, com nove táxons cada. Entre os 23 táxons, 13 são citados pela primeira vez para o Brasil Central: P. angusta var. angusta, P. angustivalva, $P$. butantanum, $P$. divergens var. biconstricta, $P$. divergens var. mesoleptiformis, $P$. gibba var. subundulata, P. paulensis, $P$. persudetica var. persudetica, $P$. subgibba var. angustarea, $P$. subgibba var. capitada, $P$. superpaulensis, $P$. viridiformis var. minor e $P$. undula var. undula.

Palavras-chave: biodiversidade, Cerrado, diatomáceas, perifíton, sistemas prístinos lóticos

\section{Introduction}

Among the various groups of organisms comprising the periphyton, diatoms stand out by its abundance among the autotrophs, due to morphological adaptations that facilitate their fixation on substrates (Stevenson 1997). Several species are able to adhere to surfaces by mucilage secreted through structures present in the valve, as the raphe, pores field apical and rimoportula (Round et al. 1990), providing them adaptive advantages (Passy 2007; Law et al. 2014). The substrate variability in lotic environments is particularly important because it affects the structure of periphyton (Cattaneo et al. 1997).

The family Pinnulariaceae D.G. Man is composed of unicellular individuals that can form short chains and are characterized by having linear-lanceolate valves, rarely elliptical, with slightly rounded apical

1. Parte da Dissertação de Mestrado do primeiro Autor

2. Universidade Federal de Goiás, Programa de Pós-Graduação em Biodiversidade Vegetal, 74690-900 Goiânia, GO, Brasil

3. Universidade Federal do Pará, Programa de Pós-Graduação em Ecologia, Belém, Pará, 66075-110 Belém, PA, Brasil

4. Universidade Estadual de Maringá, Programa de Pós-Graduação em Ecologia de Ambientes Aquáticos Continentais, 87020-900 Maringá, PR, Brasil

5. Universidade Católica de Brasília, Laboratório de Biodiversidade Aquática, 71966-700 Brasília, DF, Brasil

6. Corresponding author: dunck.barbara@gmail.com 
end, which can be capitate to subcapitate to lightly cuneate (Round et al. 1990, Rocha \& Bicudo 2008). The striae are alveolate chamber-shaped that extend from the sternum towards the ends of the valve. These alveolate structures are open to the outside through pores with occlusion of hymen type (Round et al. 1990). This family comprises genera such as Caloneis Cleve, Diatomella Greville, Dimidiata Hajós, Ostrupia Heiden ex Hustedt and Pinnularia Ehrenberg (Tremarin et al. 2010).

Pinnularia Ehrenberg is characterized by solitary individuals, rarely colonial. The valves can be linear, lanceolate or elliptical, with straight or wavy edges and rounded apical end, rostrate or capitates (Round et al. 1990). According to Guiry \& Guiry (2016), 728 taxa have been flagged as taxonomically accepted within this genus. It occurs worldwide in freshwater environments of different $\mathrm{pH}$ and trophic states, with preference to slightly acidic oligotrophic environments, and in a smaller proportion, in moist soils and marine coastal environments (Metzeltin \& Lange-Bertalot 1998; Krammer 2000).

Despite the high number of species and the frequent occurrence in freshwater environments, there is still scarce information about Pinnularia in Brazil (Tremarin et al. 2010), mainly in the central region (Silva et al. 2011). Some studies can be cited for Amazonian region (Pereira et al. 2012, 2013, 2014), São Paulo (Rocha et al. 2008) and Paraná States (Brassac \& Ludwig 2006, Tremarin et al. 2010), and Goiás (Silva et al. 2016).

Taxonomic studies on periphytic diatom algal flora in central Brazil are in early stage. The works of Souza \& Moreira-Filho (1999), Delgado \& Souza (2007) e Silva et al. (2016) are so far the only ones with descriptions of Pinnularia. Moreover, there is no available information about diatom communities in aquatic systems of the conservation units considered in this study. Present work aimed at surveying the genus Pinnularia in the periphyton of preserved streams from central Brazil located in three conservation units.

\section{Material and methods}

This study was carried out in five low order streams located in three conservation units from central Brazil: Brasilia National Park (hereafter, BNP), Chapada dos Veadeiros National Park (hereafter, CVNP) and Terra Ronca State Park (hereafter, TRSP) (figure 1). The region is occupied by the Cerrado domain (Brazilian savanna), where climate is rainy tropical, with strong seasonality. There is a rainy season from October to April concentrating up to $80 \%$ of annual precipitation (mean temperature around $29^{\circ} \mathrm{C}$ ), and a dry season from May to September when precipitation ranges from zero to below $50 \mathrm{~mm}$ (mean temperature around $18^{\circ} \mathrm{C}$ ) (Silva et al. 2008).

Between streams, BNP is located in the Federal District of Brazil, near the Brazilian capital, Brasília. CVNP and TRSP are located in Goiás State (table 1). TRSP comprises the largest cave complex in South America, and the streams sampled in this area crosses caves with their respective names (Lapa and São Mateus). The total number of sampling units was 25, considering different substrates and two seasons, as will be described below.

Periphyton was collected during the dry (August) and rainy (March) seasons, between the years 2012 and 2013, according to the protocols established by the ComCerrado Network (unpublished data). In each stream it was delimited a $50 \mathrm{~m}$ longitudinal transect, where the following substrates, wherever possible, were considered: leaf litter (L), macrophytes (M), roots $(\mathrm{R})$, trunk $(\mathrm{T})$, pebble $(\mathrm{P})$ and sand $(\mathrm{S})$ (table 1). It was used a syringe to collect sand; macrophytes were squeezed and the other substrates were scraped with a toothbrush, using distilled water gentle jets. Samples were preserved in 3-5\% formalin solution and deposited in the Herbarium of the University of Goiás (UFG). Along with periphyton, some abiotic variables (water temperature, dissolved oxygen, $\mathrm{pH}$ and electrical conductivity) were measured in the field using standard electrodes (Yellow Spring Instruments) (table 2).

Periphyton samples were cleaned using the oxidation method of Simonsen (1974) modified by
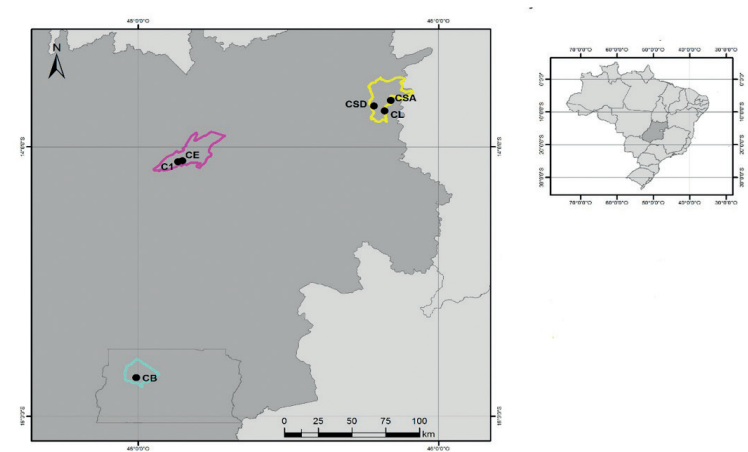

Figure 1. Study area map of the sampling stations in three conservation units (Streams C1- Córrego 1, CE- Estiva, CB: Bananal, CSD- São Mateus after cave, CSA- São Mateus before cave, CL- Lapa) from central Brazil (Brasilia National Park, Chapada dos Veadeiros National and Terra Ronca State Park). Parque Nacional da Chapada dos Veadeiros,___ Parque Estadual Terra Ronca, _ Sampling stations. 
Table 1. Geographical coordinates of sampling stations and general information about number of samples (CU: conservation unit; substrates: L: leaf litter, M: macrophytes, R: roots, T: trunk, P: pebble, S: sand).

\begin{tabular}{|c|c|c|c|c|c|c|c|}
\hline \multirow{2}{*}{$\mathrm{CU}$} & \multirow{2}{*}{ Stream } & \multirow{2}{*}{ Geographical coordinates } & \multirow{2}{*}{$\begin{array}{l}\text { Altitude } \\
\text { (m) }\end{array}$} & \multicolumn{2}{|c|}{ Dry season } & \multicolumn{2}{|c|}{ Rainy season } \\
\hline & & & & $\mathrm{N}$ & substrates & $\mathrm{N}$ & substrates \\
\hline BNP & Bananal & $15^{\circ} 42^{\prime} 50.23^{\prime \prime S ~} 48^{\circ} 0^{\prime} 45.03^{\prime \prime W}$ & 1082 & 2 & $\mathrm{M}, \mathrm{R}$ & 2 & $\mathrm{M}, \mathrm{R}$ \\
\hline CVNP & Córrego 1 & $14^{\circ} 06^{\prime} 13.5^{\prime \prime S} 47^{\circ} 42^{\prime} 19.5^{\prime \prime} \mathrm{W}$ & 1172 & 6 & $\begin{array}{c}\mathrm{L}, \mathrm{M}, \mathrm{R}, \mathrm{T}, \\
\quad \mathrm{P}, \mathrm{S}\end{array}$ & 4 & $\mathrm{~L}, \mathrm{M}, \mathrm{T}, \mathrm{P}$ \\
\hline CVNP & Estiva & $14^{\circ} 06^{\prime} 40.3^{\prime \prime S} 47^{\circ} 44^{\prime} 02.2^{\prime \prime} \mathrm{W}$ & 1162 & 3 & M, T, S & 2 & $\mathrm{P}, \mathrm{S}$ \\
\hline TRSP & Lapa & $13^{\circ} 44^{\prime} 4.38^{\prime \prime S} 46^{\circ} 21^{\prime} 24.38^{\prime \prime W}$ & 602 & 2 & $\mathrm{~T}, \mathrm{~S}$ & 1 & $\mathrm{~S}$ \\
\hline TRSP & São Mateus & $13^{\circ} 39^{\prime} 20.86^{\prime \prime} \mathrm{S} \quad 46^{\circ} 18^{\prime} 58.78^{\prime \prime} \mathrm{W}$ & 712 & 2 & $\mathrm{M}, \mathrm{R}$ & 1 & $\mathrm{P}$ \\
\hline
\end{tabular}

Table 2. Abiotic variables in the streams sampled (dry and rainy seasons) (CU: conservation unit).

\begin{tabular}{lcccccc}
\hline CU & Stream & Date & $\begin{array}{c}\text { Water temperature } \\
\left({ }^{\circ} \mathrm{C}\right)\end{array}$ & $\mathrm{pH}$ & $\begin{array}{c}\text { Electrical } \\
\text { conductivity } \\
\left(\mu \mathrm{S} \mathrm{cm}^{-1}\right)\end{array}$ & $\begin{array}{c}\text { Dissolved oxygen } \\
\left(\mathrm{mg} \mathrm{L}^{-1}\right)\end{array}$ \\
\hline CVNP & Córrego 1 & $07 / 08 / 2012$ & 18.0 & 6.65 & 13.0 & 6 \\
CVNP & Córrego 1 & $12 / 03 / 2013$ & 21.9 & 6.53 & 8.6 & 6.9 \\
BNP & Bananal & $24 / 07 / 2012$ & 20.2 & 5.57 & 5.4 & 2.5 \\
BNP & Bananal & $28 / 02 / 2013$ & 21.5 & 5.19 & 13.5 & 2.4 \\
CVNP & Estiva & $08 / 08 / 2012$ & 25.1 & 6.54 & 3.0 & 7.2 \\
CVNP & Estiva & $13 / 03 / 2013$ & 22.1 & 6.82 & 4.8 & 7.6 \\
TRSP & Lapa & $28 / 03 / 2013$ & 26.4 & 7.82 & 26.4 & 7.9 \\
TRSP & Lapa & $16 / 09 / 2013$ & 26.4 & 7.53 & 8.0 & 7.8 \\
TRSP & São Mateus & $29 / 03 / 2013$ & 25.1 & 5.72 & 5.5 & 7.0 \\
TRSP & São Mateus & $17 / 09 / 2013$ & 24.2 & 7.25 & 124.4 & 7.2 \\
\hline
\end{tabular}

Moreira-Filho \& Valente-Moreira (1981). The samples were fixed on permanent mounts with $\operatorname{Naphrax}^{\circledR}$ resin. Taxonomical analyzes were performed using a light microscope Leica DM500 equipped with digital camera ICC50Hd. The identification was based on valve morphological and morphometric features, using both classic (e.g., Hustedt 1965, Krammer 2000, Metzeltin \& Lange-Bertalot 1998, 2007) and regional literature (e.g., Rocha \& Bicudo 2008, Tremarin et al. 2010, Pereira et al. 2012). We observed at least five individuals of each species to the identification. The classification system used was Round (1991).

\section{Results and Discussion}

Altogether 23 taxa were recorded for genus Pinnularia (table 3). This genus is the second with higher species richness in Brazil (125 species) according to Menezes et al. (2015), followed only by Cosmarium ex
Ralfs (Conjugatophyceae) with 156 species. Our study contributed with the record of 13 taxa not yet reported for the central Brazil, and this number is very representative to Pinnularia species compared to 53 species cited by Silva et al. (2011) for the Central-West region.

The most frequent species were $P$. subanglica, $P$. angustivalva and $P$. butantanum, present in more than $20 \%$ of the samples. Among the streams analyzed, Córrego 1 and Estiva were the richest ones, with 11 and nine taxa, respectively (table 3 ). These streams are located at CVNP, and presented the highest variety of substrates. Pebble and sand were the richest substrates, with nine taxa of Pinnularia, followed by trunk (seven), macrophytes (seven), leaf litter (six) and roots (four).

An identification key is presented with the identified taxa, followed by description, comments, distribution in the central Brazil and illustration of the examined material.

\section{Identification key of species of Pinnularia Ehrenberg}

1. Central area rhombic

2. Valves linear

3. Raphe undulate. P. subgibba var. capitada

3. Raphe filiform 
4. Apices subcapitate

5. Apical axis between $45.22-52.78$ P. divergens var. media

5. Apical axis between $54.44-60.58 \mu \mathrm{m}$ P. gibba var. subundulata

4. Apices in another shape

6. Apices rostrate

P. microstauron var. rostrada

6. Apices capitate P. subanglica

2. Valves linear lanceolate

7. Raphe linear complex P. mesoloptiformis

7. Raphe undulate

8. Apical axis between $81.52-82.13 \mu \mathrm{m}$

P. divergens var. biconstricta

8. Apical axis between 72.4-76.91 $\mu \mathrm{m}$ P. divergens var. protracta

1. Central area in another shape

9. Raphe straight

10. Valves elliptic-lanceolate

Pinnularia sp. 1

10. Valves lanceolate

11. Apices subcapitate to capitate

P. brauniana

11. Apices rostrate to cuneate

9. Raphe in another shape

Pinnularia sp. 4

12. Central area rectangle reaching the valve margins

P. angustivalva

12. Central area semi-circle to asymmetric

13. Apices rostrate

P. meridiana var. meridiana

13. Apices in another shape

14. Apices rounded-cuneate with valve transapical axis between 14.4-14.88 $\mu \mathrm{m}$

15.9 striae in $10 \mu \mathrm{m}$

P. persudetica var. persudetica

15. 10 striae in $10 \mu \mathrm{m}$ $P$. viridiformis var. minor

14. Apices rounded to capitate with valve transapical axis between $7.44-15.77 \mu \mathrm{m}$

16. Central area asymmetric

17. 13 striae in $10 \mu \mathrm{m}$

P. angusta var. angusta

17. 12 striae in $10 \mu \mathrm{m}$

Pinnularia sp. 3

16. Central area in circle shape or semi-circle

18. Central area semi-circle in one of the sides of the valve and asymmetric in the other side

19. 11 striae in $10 \mu \mathrm{m}$

Pinnularia sp. 2

19. 14 striae in $10 \mu \mathrm{m}$

21. Apical axis $89.76 \mu \mathrm{m}$

P.paulensis

21. Apical axis between 128.67-129.38 $\mu \mathrm{m}$

P. superpaulensis

18. Central area semi-circle in both sides of the valve

20. Apices conic

P. castraregina

20. Apices in another shape

22. Valves margin straight and the middle region istumescent

P. subgibba var. angustera

22. Valves margin strongly undulate in the middle region

P. undula var. undula

Bacillariophyta

Bacillariophyceae

Naviculales

Pinnulariaceae D.G.Man

Pinnularia Ehrenberg

Pinnularia angusta var. angusta (Cleve) Krammer, In Krammer, Biblioth.Diatomol. 26:122. 1992.

Figure 2
The valves are linear with triundulate margins and a slight inflation in the middle region; apices are capitate to subcapitate; raphe filiform; central area asymmetric; Striae are often slightly bent, radiate near the valve center and become convergent in the end. Apical axis: $48.88 \mu \mathrm{m}$; transapical axis: $7.74 \mu \mathrm{m}$; rate apical axis/transapical: $6.31 \mu \mathrm{m}$; 13 striae in $10 \mu \mathrm{m}$.

Pinnularia angusta var. angusta has morphological characteristics such as frustule shape and similar striae 
Table 3. Occurrence of Pinnularia Ehrenberg in Cerrado streams during dry and rainy seasons, in different substrates and species richness by stream (L: leaf litter, M: macrophytes, P: pebble, R: roots, S: sand, T: trunk).

\begin{tabular}{|c|c|c|c|c|c|c|c|c|c|c|c|c|c|c|c|c|c|c|c|c|c|c|c|c|}
\hline \multirow{3}{*}{ Species } & \multicolumn{4}{|c|}{ Bananal } & \multicolumn{10}{|c|}{ Córrego 1} & \multicolumn{5}{|c|}{ Estiva } & \multicolumn{2}{|c|}{ Lapa } & \multicolumn{3}{|c|}{ São Mateus } \\
\hline & \multicolumn{2}{|c|}{ Dry } & \multicolumn{2}{|c|}{ Rainy } & & \multicolumn{4}{|c|}{ Dry } & \multicolumn{5}{|c|}{ Rainy } & \multicolumn{3}{|c|}{ Dry } & \multicolumn{2}{|c|}{ Rainy } & Dry & \multirow{2}{*}{$\begin{array}{c}\text { Rainy } \\
\mathrm{S}\end{array}$} & \multicolumn{2}{|c|}{ y Dry } & \multirow{2}{*}{$\frac{\text { Rainy }}{\mathrm{P}}$} \\
\hline & $\mathrm{M}$ & $\mathrm{R}$ & $\mathrm{M}$ & $\mathrm{R}$ & $\mathrm{L}$ & $\mathrm{M}$ & $\mathrm{R}$ & $\mathrm{T}$ & $\mathrm{P}$ & $\mathrm{S}$ & $\mathrm{L}$ & $\mathrm{M}$ & $\mathrm{T}$ & $\mathrm{P}$ & $\mathrm{M}$ & $\mathrm{T}$ & $\mathrm{S}$ & $\mathrm{P}$ & $\mathrm{S}$ & $\mathrm{T}$ & & $\mathrm{M}$ & $\mathrm{R}$ & \\
\hline P. angusta & & & & & & & & & & & & & $\mathrm{X}$ & & & & & & & & & & & \\
\hline P. angustivalva & & & & & $\mathrm{X}$ & $\mathrm{X}$ & & & $\mathrm{X}$ & $\mathrm{X}$ & & $\mathrm{X}$ & & & & & & & & & & & & \\
\hline P. brauniana & & & & & & & & & $\mathrm{X}$ & & & & $\mathrm{X}$ & $\mathrm{X}$ & & & & $\mathrm{X}$ & & & & & & \\
\hline P. butantanum & & & & & $\mathrm{X}$ & & & $\mathrm{X}$ & $\mathrm{x}$ & $\mathrm{X}$ & & & & & $\mathrm{X}$ & $\mathrm{X}$ & & & & & & & & \\
\hline P. divergens var. biconstricta & & & & & & & & & & & & & & $\mathrm{X}$ & & & & & & & & & & \\
\hline P. divergens var. media & & & & & & & & & & & & & & & & & & & & & $\mathrm{X}$ & & $\mathrm{X}$ & \\
\hline $\begin{array}{l}\text { P. divergens } \text { var. } \\
\text { mesoleptiformis }\end{array}$ & & & & & & & & & & & & & & & & & & & & & $\mathrm{X}$ & & & \\
\hline P. gibba var. subundulata & & & & & & & & & & & & & & $\mathrm{X}$ & & & & $\mathrm{X}$ & & & & & & \\
\hline P. meridiana var. meridiana & & & & & & & & & & & & & & & & & & & & & & $\mathrm{X}$ & & \\
\hline P. microstrauron & & & & & & & & & & & & & & & & & & & & & & & $\mathrm{X}$ & \\
\hline P. paulensis & & & & & & & & & & & & & & & & & $X$ & & & & & & & \\
\hline P. persudetica var. persudetica & & & $\mathrm{X}$ & & & & & & & & & & & & & & & & & & & & & \\
\hline P. subanglica & & & & & & & & $\mathrm{X}$ & & & $\mathrm{X}$ & & $\mathrm{X}$ & $\mathrm{X}$ & $\mathrm{X}$ & $\mathrm{X}$ & & & $\mathrm{X}$ & & $\mathrm{X}$ & & & \\
\hline P. subgibba var. angustarea & & & $\mathrm{X}$ & & & & & & & & & & $\mathrm{X}$ & & & & & $\mathrm{X}$ & & & & & & \\
\hline P. superpaulensis & & & & & $\mathrm{X}$ & & & & & & & & & & & & & & & & & & & \\
\hline P. viridiformis var. minor & & & & & $\mathrm{X}$ & & & & & & & & $\mathrm{X}$ & & & & & & & & & & & \\
\hline P. undula var. undula & & & & & & & & & & & & & & & & & $\mathrm{X}$ & $\mathrm{X}$ & & & & & & \\
\hline Pinnularia sp.1 & & & & & & & & & & & & & & & & & & & & $\mathrm{X}$ & & & & \\
\hline Pinnularia sp. 2 & & & & & & & & & & & & & & & & & & $\mathrm{X}$ & & & & & & \\
\hline Pinnularia sp. 3 & & & & & & & & & & & & & & & & & $\mathrm{X}$ & & & & & & & \\
\hline Pinnularia sp.4 & & $\mathrm{X}$ & & & & & & & & & & & & & & & & & & & & & & \\
\hline Pinnularia sp. 5 & & $\mathrm{x}$ & $\mathrm{X}$ & & & & & & & & & & & & & & & & & & & & & \\
\hline Pinnularia sp.6 & & & & & & $\mathrm{X}$ & & & $\mathrm{X}$ & $\mathrm{X}$ & & & & & & & & & & & & & & \\
\hline Species richness & & 4 & & & & & & & 1 & 1 & & & & & & & 9 & & & & 4 & & 3 & \\
\hline
\end{tabular}

as Pinnularia grunowii Krammer and Pinnularia pluvianiformis Krammer. These two species have differences mainly in the the rate apical axis/transapical. Krammer (2000) describes the rates between 3.7-5.4 for Pinnularia grunowii and 4.5 for Pinnularia pluvianiformis, and $P$. angusta is between 5.5-8.5. In northern Europe, the distribution related to this species is mainly in oligotrophic environments with low electrolytes (Krammer 2000).

Midwest region records: pioneer reference.

Occurence in the samples: BRAZIL. GoiÁs: Parque Nacional da Chapada dos Veadeiros, Córrego 1, A. A. França 9 (UFG 50251).

Pinnularia angustivalva Krammer \& Metzeltin, In Lange-Bertalot, Iconographia Diatomologica 5:164, pl. 190, figs. 10-11. 1998.

Figures 3-7
The valves are lanceolate with parallel margins to slightly convergent; the middle region has inflation; Apices are cuneate-rounded; raphe is lateral with distal ends deflected; central area is a rectangle reaching the valves margins; shorter and parallel striae. Apical axis: 51.86-65.41 $\mu \mathrm{m}$; transapical axis: 8.33-11.01 $\mu \mathrm{m}$; rate apical axis/transapical: $5.19-7.29 \mu \mathrm{m} ; 11-13$ striae in $10 \mu \mathrm{m}$.

Pinnularia instabiliformis Krammer \& Metzeltin shows similar valves shape and striation as Pinnularia angustivalva, however the difference is on the apical and transapical axis' measures that are larger. Pinnularia acuminate var. guyanensisis quite confused with $P$. instabiliformis, but the first one has bigger valves (apical axis $70-110 \mu \mathrm{m}$ and transapical axis 15-6 $\mu \mathrm{m}$ ) and the apices are less cuneiform (Metzeltin 

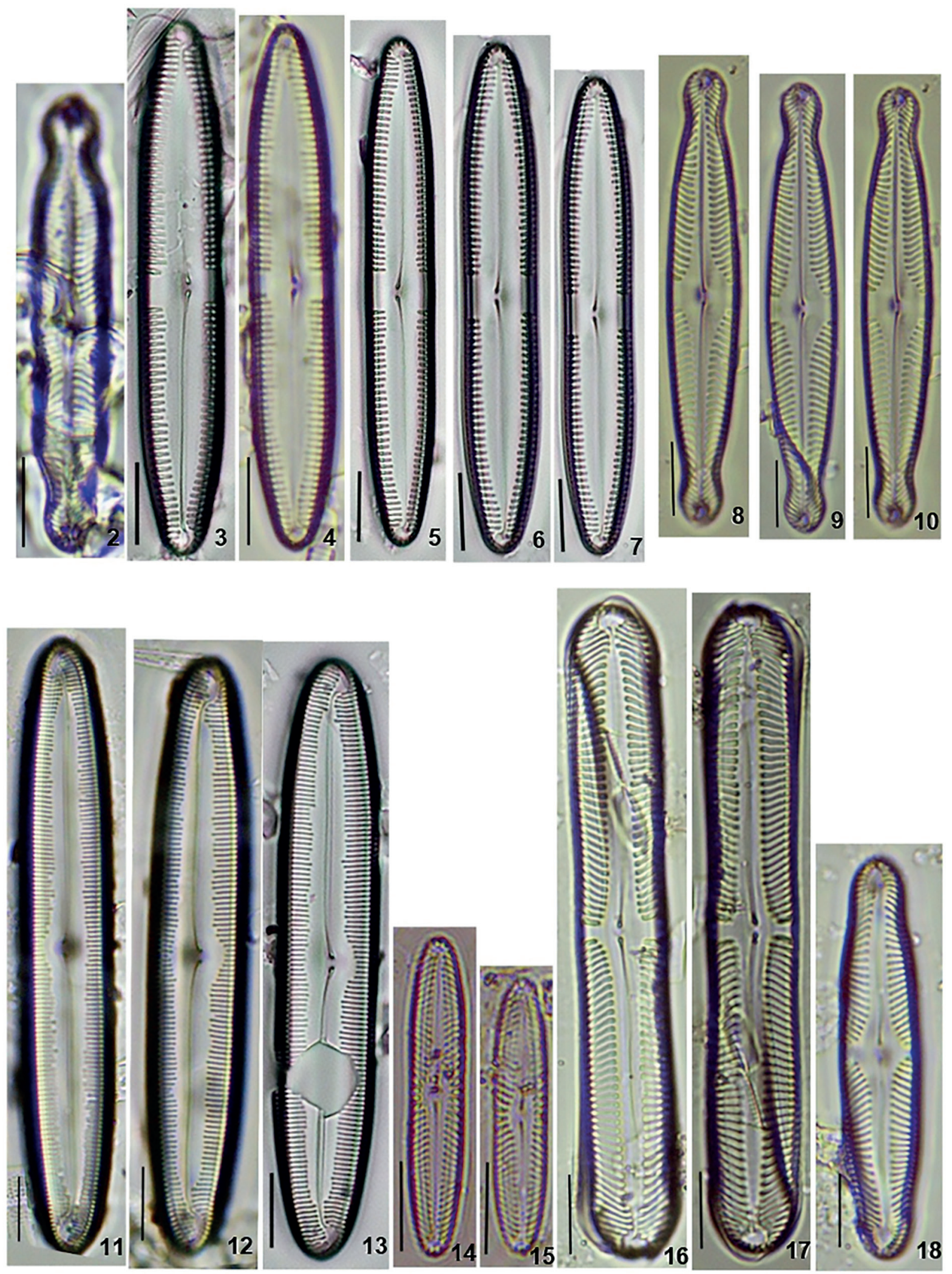

Figures 2-18. Pinnularia species in Cerrado streams. 2. Pinnularia angusta var. angusta. 3-7. Pinnularia angustivalva. 8-10. Pinnularia brauniana. 11-13. Pinnularia butantanum. 14-15. Pinnularia sp.5. 16-17. Pinnularia divergens var. biconstricta. 18. Pinnularia divergens var. media. Scale $=10 \mu \mathrm{m}$. 
\& Lange-Bertalot 2007). The observed individuals had bigger transapical axis then the specimens found on Negro river (transapical axis 32-54 $\mu \mathrm{m}$ ) by Metzletin \& Lange-Bertalot $(1998 ; 2007)$, but the dimensions fit with the description of the species and the original illustrations.

Midwest region records: pioneer reference.

Occurence in the samples: BRAZIL. GoIÁs: Parque Nacional da Chapada dos Veadeiros, Córrego 1, $A$. A. França 9 (UFG 50251); Córrego 1, A.A. França 7 (UFG50249); Córrego Estiva, A.A. França 18 (UFG50260); A.A. França 21 (UFG50263).

Pinnularia brauniana (Grunow) Studnicka, In Verhandlungen der Kaiserlich-Koniglichen Zoologisch-Botanischen Gesellschaft in Wein 38:737. 1888.

Figures 8-10

The valves are lanceolate with a slightly convex side; apices are subcapitate to capitate; raphe is straight with a narrow sternum; axial area is lanceolate widening into the middle region; central area is semirhombic formed by shortening of the middle striae and a siliceous space reaching the valve margin; striae are radiate and convergent near the apices. Apical axis: 53.18-63.32 $\mu \mathrm{m}$; transapical axis: 9.18-10.86 $\mu \mathrm{m}$; rate apical axis/transapical: 5.18-6.34 $\mu \mathrm{m}$; 10-12 striae in $10 \mu \mathrm{m}$.

Pinnularia subcapitada Gregory is close to P. brauniana because their valves are lanceolate with subcapitate to capitate apices, but they differ on a narrow axial area and a small transapical axis (Krammer 1992).

Midwest region records: Federal District (Delgado \& Souza 2007).

Occurence in the samples: BRAZIL. GoIÁs: Parque Nacional da Chapada dos Veadeiros, Córrego 1, A.A. França 5 (UFG50247); Córrego 1, A.A. França 5 (UFG50251); Córrego 1, A.A. França 7 (UFG50249); Córrego Estiva, A.A. França 18(UFG50260); Córrego Estiva, A.A. França 21 (UFG50263).

Pinnularia butantanum (Krasske) Metzeltin, Iconographia Diatomologica 5:628, pl. 197, figs 1-3. 1998.

Figures 11-13

The valves are lanceolate to elliptic-lanceolate with apices lightly rounded; raphe is straight formed by a deflected hook shape on the apices; central area is slightly rounded and asymmetric. Apical axis: 73.47-91.32 $\mu \mathrm{m}$; transapical axis: 11.18-14.22 $\mu \mathrm{m}$; rate apical axis/transapical: 5.92-8.16 $\mu \mathrm{m} ; 13-15$ striae in $10 \mu \mathrm{m}$.

According to Lange-Bertalot (1998) Caloneis westii (Wm. Simith) Hendey has a morphologic valve and striation similar to $P$. butantanum, although $C$. westii differs mainly because of the attenuated form of the apices and the raphe sternum is narrower.

Midwest region records: pioneer reference.

Occurence in the samples: BRAZIL. GoIÁs: Parque Nacional da Chapada dos Veadeiros, Córrego 1, A.A. França 7 (UFG 50 249); Córrego 1, A.A. França 1 (UFG 50 243); Córrego 1, A.A. França 4 (UFG 50 246); Córrego 1, A.A. França 3 (UFG 50 245); Córrego Estiva, A.A. França 23 (UFG 50 248).

Pinnularia divergens var. biconstricta (Cleve-Euler) Cleve-Euler, In Cleve-Euler, Die Diatommen von Schweden und Finnland 5(4):1-232, figs. 971-1306. 1955.

Figures 16-17

The valves are linear lanceolate with apices rounded; rhape is slightly undulate with deflected distal ends; the valve middle region has a slight inflation; central area is rhombic widening to a small siliceous fascia; striae are radiate to convergent on the apices. Apical axis: 81.52-82.13 $\mu \mathrm{m}$; transapical axis: $11.39-11.91 \mu \mathrm{m}$; rate apical axis/transapical: 6.89-7.15 $\mu \mathrm{m} ; 10-11$ striae in $10 \mu \mathrm{m}$.

The specimes of this study are smaller than that illustrated by Tremarin et al. (2010) for $P$. divergens var. biconstricta. They are similar in the valves characteristics, striation and rhombic central area. According to Krammer (2000), the valves are linear and the valves margins commonly parallel, similar to that found in our study. The specimes differ from $P$. divergens var. malayensis mainly by the undulation on the valves margin, as illustrated by Tremarin et al. (2010) and Rocha et al. (2008) for P. divergens var. malayensis. Pinnularia divergens var. biconstricta have planktonic habitat and is found in standing water, but can occur running water (Moro \& Fürstenberger 1997).

Midwest region records: pioneer reference.

Occurence in the samples: BRAZIL. GoIÁs: Parque Nacional da Chapada dos Veadeiros, Córrego 1, A. A. França 5 (UFG 50 247). 
Pinnularia divergens var. media Krammer, In Lange-Bertalot, Diatoms of Europe 1:61, pl.34, figs. 1-5. 2000.

Figure 18

The valves are linear with apices subcapitate; raphe is filiform; central area is rhombic reaching the edges of the valve; striae are radiate to convergent on the apices. Apical axis: 45.22-52.78 $\mu \mathrm{m}$; transapical axis: $8.89-10.44 \mu \mathrm{m}$; rate apical axis/transapical: 5.05-5.08 $\mu \mathrm{m}$; $10-11$ striae in $10 \mu \mathrm{m}$.

This variety differs from the variety type, by presenting a smaller apical and transapical axis (Krammer 2000). Pinnularia divergens var. media prefers oligotrophic environments with low mineral contents (Krammer 2000). The observed specimens had shown a bigger transapical axis and less striae compared with specimens found in Guaraguaçu's river (apical axis 33.1-49.4 $\mu \mathrm{m}$; 12-14 striae in $10 \mu \mathrm{m}$ ) by Tremarin et al. (2010), but the dimensions fit with the description of the species and the original illustrations.

Midwest region records: District Federal (Delgado \& Souza 2007); Goiás (Delgado \& Souza, 2007).

Occurence in the samples: BRAZIL. GoIÁs: Parque Nacional de Terra Ronca, Córrego Lapa, A.A. França 25 (UFG 50 267); Córrego São Mateus, A.A. França 15 (UFG 50 257).

Pinnularia divergens var. mesoleptiformis Krammer \& Metzeltin, In Lange-Bertalot, Iconographia Diatomologica 5:170, pl. 173, figs. 1-4. 1998.

Figure 19

The valves are linear-lanceolate, with triundulate margins and the central undulation is wider than the distal undulation; apices are capitate; raphe is linear and complex; central area is rhombic with a siliceous space on the middle region of the valve; striae are radiate and convergent towards the apices. Apical axis: $76.71 \mu \mathrm{m}$; transapical axis: $12.54 \mu \mathrm{m}$; rate apical axis/ transapical: $6.11 \mu \mathrm{m}$; 11 striae in $10 \mu \mathrm{m}$.

The original description of $P$. divergens var. mesoleptiformis put this species similar to $P$. divergens var. laticeps Franquelli, showing only difference on the transapical axis' measures, which in Pinnularia divergens var. laticepes always is smaller, 13,4 $\mu \mathrm{m}$ against $20 \mu \mathrm{m}$. Although, illustrated in Metzeltin \& Lange-Bertalot (1998) and Frenguelli (1933) we realize that besides the length range of the valves, both varieties differs on the apices' shape and type of the raphe. At Pinnularia divergens var. laticeps the apices are capitate with a small flatness and the raphe is filiform, yet Pinnularia divergens var. mesoleptiformis has apices capitate and stretched and the raphe is complex.

Midwest region records: pioneer reference.

Occurence in the samples: BRAZIL. GoIÁs: Parque Nacional de Terra Ronca, Córrego Lapa, A.A. França 25 (UFG 50 267).

Pinnularia gibba var. subundulata (Mayer ex Hustedt) Frenguelli, In Anales Del Museo Nacional de História Natural 37:365-475, pl. 9. 1933.

Figures 21-23

The valves are linear with slight undulations on the margins; apices are subcapitate; raphe is filiform with distal end deflected to the same direction and in a hook shape; central area is rhombic reaching the margins; striae are strongly radiate to convergent on the apices. Apical axis: 54.44-60.58 $\mu \mathrm{m}$; transapical axis: 8.74-9.19 $\mu \mathrm{m}$; rate apical axis/transapical: 6.14$7.06 \mu \mathrm{m}$; $10-11$ striae in $10 \mu \mathrm{m}$.

Pinnularia subggiba var. undula Krammer differs from $P$. gibba var. subundulata (Mayer) Frenguelli for having slightly capitate apices and a wide sternum (Krammer 1992).

Midwest region records: pioneer reference.

Occurence in the samples: BRAZIL. GoIÁs: Parque Nacional da Chapada dos Veadeiros, Córrego 1, A.A. França 5 (UFG 50 247); Córrego Estiva, A.A. França 21 (UFG 50 263).

Pinnularia meridiana var. meridiana Metzeltin \& Krammer, In Lange-Bertalot, Iconographia Diatomologica 5: 180, pl. 181, figs. 1-5. 1998.

Figure 24

The valves are linear-elliptic with parallel margins to slightly convex; apices are slightly rostrate to rounded; raphe is lightly lateral with terminal indistinct fissures; a semi-circle is formed in the central are by shortening of the striae on the middle region; transapical striae parallels to slightly radiate on the center of the valve. Apical axis: $45.02 \mu \mathrm{m}$; transapical axis: $9.87 \mu \mathrm{m}$; rate apical axis/transapical: $4.56 \mu \mathrm{m} ; 10$ striae in $10 \mu \mathrm{m}$.

$P$. meridiana var. meridiana distinguishes from $P$. var. parallela, by showing parallel to slightly convex margins and apices are slightly rounded, while $P$. var. parallela has parallel margins and apices strongly 

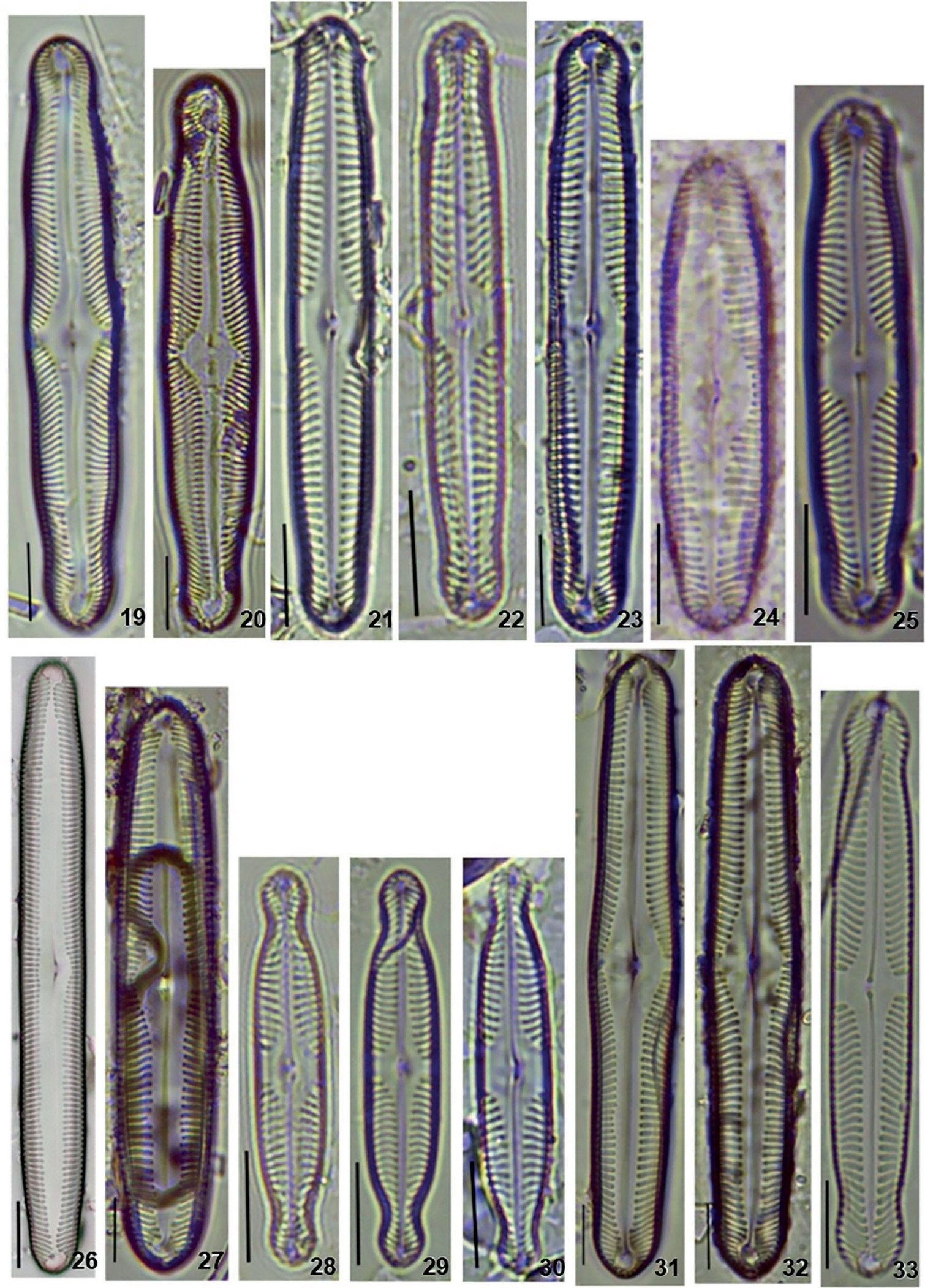

Figures 19-33. Pinnularia species in Cerrado streams. 19. Pinnularia divergens var. mesoleptiformis. 20. Pinnularia sp. 6. 21-23. Pinnularia gibba var. subundulata. 24. Pinnularia meridiana var. meridiana. 25. Pinnularia microstrauron. 26. Pinnularia paulensis. 27. Pinnularia persudetica var. persudetica. 28-30. Pinnularia subanglica. 31-32. Pinnularia subgibba var. angustarea. 33. Pinnularia subgibba var. capitada. Scale $=10 \mu \mathrm{m}$. 
rounded (Metzeltin \& Lange-Bertalot 1998). The specimen of $P$. meridian var. meridian found on this study has similarity with the illustrated in Metzeltin \& Krammer (1998), differing on the transapical axis, which according to the author are 12 to $13 \mu \mathrm{m}$.

Midwest region records: Silva et al. (2016).

Occurence in the samples: BRAZIL. GoIÁs: Parque Nacional de Terra Ronca, Córrego São Mateus, A.A. França 17 (UFG 50 259).

Pinnularia microstrauron (Ehrenberg) Cleve, The diatoms of Finland, Acta Societatia pro Fauna et Flora Fennica 8(2): 1-68, pls 1-3. 1891.

Figure 25

The valves are linear with slightly convex margins; apices are rostrate; raphe is filiform; central area is rhombic reaching the margins due to a siliceous space formed by shortening of the striae on the center; striae are radiate and convergent towards the apices. Apical axis: $45.26 \mu \mathrm{m}$; transapical axis: $8.61 \mu \mathrm{m}$; rate apical axis/transapical: $5.25 \mu \mathrm{m} ; 13$ striae in $10 \mu \mathrm{m}$.

The specimens are similar to that illustrated by Krammer \& Metzeltin (1998, table 172 pg 578, figs. 6-8) manly in the valve format, striae and the straight proximal raphe ends. This is cosmopolite species, have been found in oligotrophic waters with low electrolytes (Krammer 2000).

Midwest region records: Silva et al. (2016).

Occurence in the samples: BRAZIL. GoIÁs: Parque Nacional de Terra Ronca, Córrego São Mateus, A.A. França 17 (UFG 50 259).

Pinnularia paulensis Grunow, In Cleve, K. Svenka Vet.-Akad.Handl. 27(3):86, pl.1, fig. 20. 1895. Figure 26

The valves are linear-lanceolate without undulations on the margins; apices are acuminaterounded; raphe is slightly undulate with terminal ends deflected to the same directions in bayonet shape; central area slightly circle on the center of the dorsal side; striae are shortened throughout all the valve complex; parallel and slightly radiate on the center. Apical axis: $89.76 \mu \mathrm{m}$; transapical axis: $9.44 \mu \mathrm{m}$; rate apical axis/transapical: $9.44 \mu \mathrm{m}$; 14 striae in $10 \mu \mathrm{m}$.

$P$. paulensis shows linear-lanceolate valves and similar apices as $P$. superpaulensis (Hustedt) Metzeltin\& Lange-Bertalot, but differs by showing simple raphe and shorter striae.
Midwest region records: pioneer reference.

Occurence in the samples: BRAZIL. GoIÁs: Parque Nacional da Chapada dos Veadeiros, Córrego Estiva, A. A. França 22 (UFG 50 264).

Pinnularia persudetica var. persudetica Krammer, In Lange-Bertalot, Diatoms Europe 1:134, pl. 109, figs 1-6. 2000.

Figure 27

The valves are linear to elliptic-lanceolate with sides lightly convex; apices are cuneate-rounded; raphe is lateral; central area is slightly round in one side of the valve, formed by shortening of the striae on the center; striae are radiate on the center and convergent on the apices. Apical axis: $86.65 \mu \mathrm{m}$; transapical axis: $14.4 \mu \mathrm{m}$; rate apical axis/transapical: $5.80 \mu \mathrm{m} ; 9$ striae in $10 \mu \mathrm{m}$.

P. persudetica var. persudetica and P. persudetica var. silvatica has ellliptic-lanceolate valves with convex sides and cuneate rounded apices. P. persudetica var. persudetica distinguishes from $P$. persudetica var. sylvatica for showing a small transapical axis and robust striae (Krammer 2000). Abundant in some oligotrophic lakes in Finland, where there is low electrolytes (Krammer 2000).

Midwest region records: pioneer reference.

Occurence in the samples: BRAZIL. GoIÁs: Parque Nacional de Brasília, Córrego Bananal, A.A. França 10 (UFG 50 250).

Pinnularia subanglica Krammer, In Lange-Bertalot, Diatoms Europe 1:108, pl. 84, figs. 1-7. 2000. Figures 28-30

The valves are linear; apices are capitate; central area is rhombic, almost reaching of the valves margins; raphe is filiform; striae are radiate on the center and convergent on the apices. Apical axis: 30.73-39.2 $\mu \mathrm{m}$; transapical axis: 5.03-7.33 $\mu \mathrm{m}$; rate apical axis/ transapical: $4.28-6.79 \mu \mathrm{m} ; 12-14$ striae in $10 \mu \mathrm{m}$.

Pinnularia subanglica has similar valve shape as Pinnularia rumrichae Krammer, but differs showing less capitate apices, width between 7-8 $\mu \mathrm{m}$ and rate apical /transapical axes of 5,8 $\mu \mathrm{m}$ (Krammer 2000). This species is not rare, can be found in water with low electrolytes and higher levels of oxygen (Krammer 2000).

Midwest region records: Federal District (Delgado \& Souza 2007); Goiás (Delgado \& Souza 2007). 
Occurence in the samples: BRAZIL. GoiÁs: Parque Nacional da Chapada dos Veadeiros, Córrego 1, A.A. França 5 (UFG 50 247); Córrego 1, A.A. França 13 (UFG 50 255); Córrego 1, A.A. França 9 (UFG 50 251); Córrego 1, A.A. França 3 (UFG 50 245); Córrego Estiva, A.A. França 18 (UFG 50 260); Córrego Estiva, A.A. França 21 (UFG 50 265); Córrego Estiva, A.A. França 19 (UFG 50 261). Parque Estadual Terra Ronca, Córrego Lapa, A.A. França 26 (UFG 50 248).

Pinnularia subgibba var. angustarea Krammer \& Metzelin, In Lange-Bertalot, Iconographia Diatomologica 5:191, pl. 184, figs 1-3. 1998.

Figures 31-32

The valves are linear with straight margins; apices are slightly protracted and rounded; raphe is straight with some undulations; central area rounded formed by shortening of the striae on the center; stria and transapical are aveolar slightly radiate and convergent on the apices. Apical axis: 89.24-123.36 $\mu \mathrm{m}$; transapical axis: 13.99-15.77 $\mu \mathrm{m}$; rate apical axis/ transapical: 6.37-8.06 $\mu \mathrm{m}$; 7-9 striae in $10 \mu \mathrm{m}$.

The illustrated individuals in this study, shows morphological characteristics as valves shape, apices, raphe, central area and striae similar to the description in Krammer (2000), but differs on the transapical axis measure $(11.6-13.7 \mu \mathrm{m})$.

Midwest region records: pioneer reference.

Occurence in the samples: BRAZIL. Goís: Parque Nacional da Chapada dos Veadeiros, Córrego 1, A.A. França 9 (UFG 50 251); Córrego Estiva, A.A. França 21 (UFG 50 251); Parque Nacional de Brasília, Córrego Bananal, A.A. França 10 (UFG 50 250).

Pinnularia subgibba var. capitada Metzeltin \& Krammer, In Lange-Bertalot, Iconographia Diatomologica 5:191, pl. 176, figs 1-3. 1998.

Figure 33

The valves are linear; apices are capitate-rounded; raphe has slight undulations; central area is rhombic with a small siliceous space reaching the margins; striae are radiate on the center and convergent on the apices. Apical axis: 49.95-75.64 $\mu \mathrm{m}$; transapical axis: 5.89-7.97 $\mu \mathrm{m}$; rate apical axis/transapical: 6.83-8.98 $\mu \mathrm{m}$; 7-9 striae in $10 \mu \mathrm{m}$.

According to Krammer (1998) Pinnularia subgibba var. capitada differs from the complex species type $P$. subgibba, by presenting an undulation to triundulation on the margins with a slightly inflation in the middle region, apices are slightly rounded.

Midwest region records: pioneer reference.

Occurence in the samples: BRAZIL. GoIÁs. Parque Nacional da Chapada dos Veadeiros, Córrego 1, A.A. França 9 (UFG 50 251)

Pinnularia superpaulensis (Hustedt) Metzeltin \& Lange-Bertalot, In Metezeltin \& Lange-Bertalot, Iconographia Diatomologica 18:226, pl. 257, figs. 1-3. 2007.

Figure 34

The valves are linear with an expansion in the center of the valve; apices are slightly cuneate-rounded; raphe is straight and filiform with distal end in a hook shape; central area is slightly rounded in one side of the valve; striae are shorter throughout all the complex of the valve, slightly radiate and convergent. Apical axis: 128.67-129.38 $\mu \mathrm{m}$; transapical axis: 14.49-14.63 $\mu \mathrm{m}$; rate apical axis/transapical: $8.84-8.87 \mu \mathrm{m} ; 14$ striae in $10 \mu \mathrm{m}$.

According to Krammer (2000) Pinnularia paulensis Grunow differs from Pinnularia superpaulensis because the raphe is simple and the striae are shorter.

Midwest region records: pioneer reference.

Occurence in the samples: BRAZIL. GoIÁs: Parque Nacional da Chapada dos Veadeiros, Córrego 1, A.A. França 9 (UFG 50 251); Córrego 1, A.A. França 1 (UFG 50243 ).

Pinnularia viridiformis var. minor Krammer, In Lange-Bertalot, Diatoms of Europe 1:168, pl. 138, figs. 1-5. 2000.

Figure 35

The valves are elliptic-lanceolate with lightly convex margins; apices are acuminate-rounded; raphe is lateral and slightly undulate with distal ends deflected to the same direction in bayonet shape; central area is rounded; striae are radiate and slightly convergent on the apices. Apical axis: $78.61 \mu \mathrm{m}$; transapical axis: $14.88 \mu \mathrm{m}$; rate apical axis/transapical: $5.28 \mu \mathrm{m} ; 10$ striae in $10 \mu \mathrm{m}$.

P. viridiformis var. minor differs from Pinnularia viridiformis var. viridiformis Krammer because the valve size is different and the raphe is complex. The illustrated individuals in this study showed less striae, when compared with the original description by Krammer (2000) which has between 7-9 striae in 

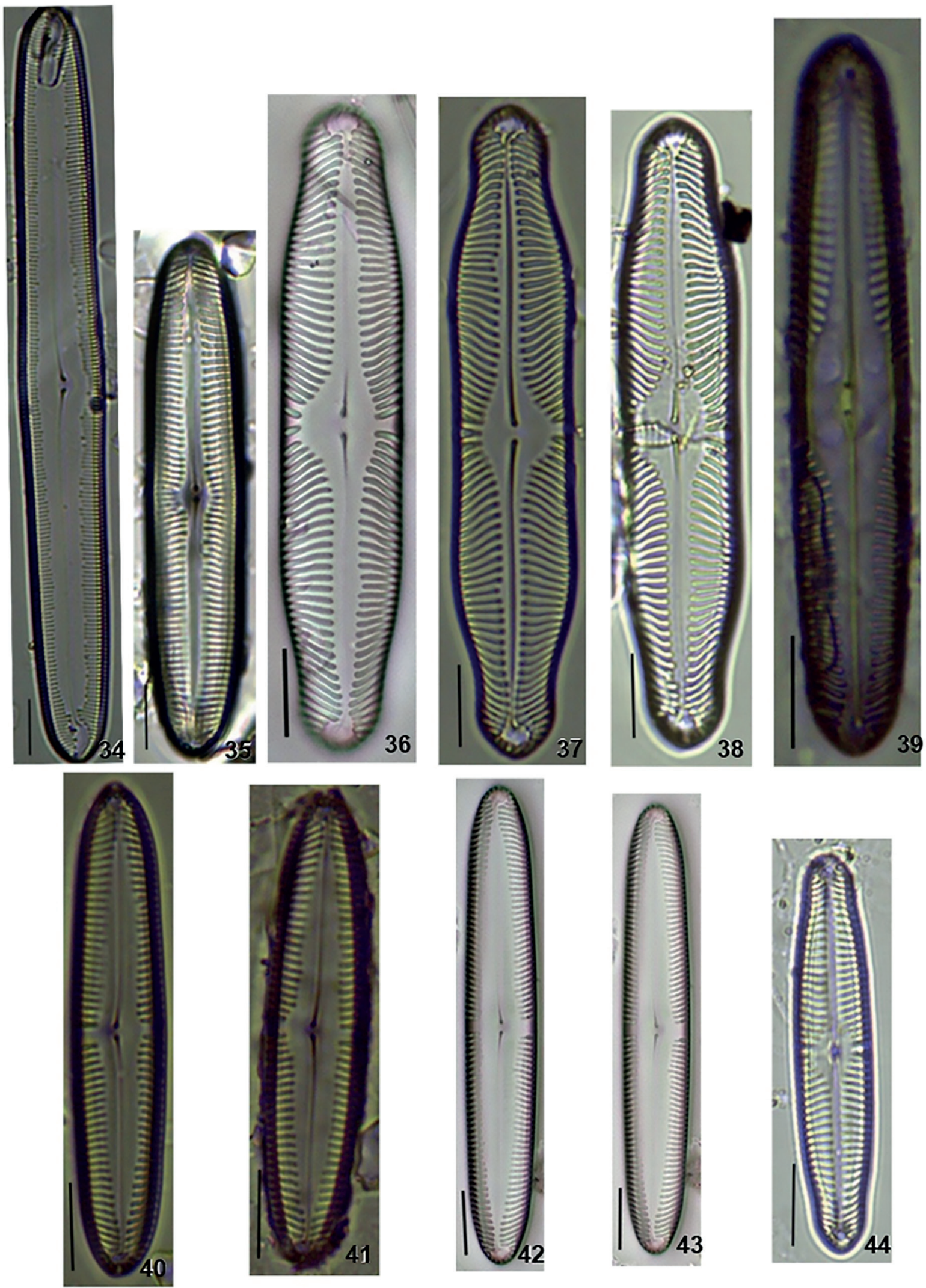

Figures 34-44. Pinnularia species in Cerrado streams. Pinnularia superpaulensis. 35. Pinnularia viridiformis var. minor. 36-38. Pinnularia undula var. undula. 39. Pinnularia sp.1. 40-41. Pinnularia sp.2. 42-43. Pinnularia sp.3. 44. Pinnularia sp.4. Scale $=10 \mu \mathrm{m}$. 
$10 \mu \mathrm{m}$. According to Krammer (2000) P. viridiformis var. minor is cosmopolite species, that can be found in different environment conditions.

Midwest region records: pioneer reference.

Occurence in the samples: BRAZIL. Goiás. Parque Nacional da Chapada dos Veadeiros, Córrego 1, A.A. França 1 (UFG 50 243).

Pinnularia undula var. undula (Schumann) Krammer, In Lange-Bertalot, Diatoms of Europe 1:122, pl. 92, figs. 3-12. 2000.

Figures 36-38

The valves are linear with slightly undulation on the margins, more evident on the center; apices are slightly subcapitate to truncate; raphe is filiform with a distal fissure in bayonet shape; central area is large and slightly rounded; striae are radiate in the center and strongly convergent on the apices. Apical axis: 73.51$79.2 \mu \mathrm{m}$; transapical axis: $13.81-15.73 \mu \mathrm{m}$; rate apical axis/transapical: 5.03-5.37 $\mu \mathrm{m}$; 8-9 striae in $10 \mu \mathrm{m}$.

$P$. undula var. undula differs from other varieties showing parallel sides or undulates, apices are subcapitate to truncate in some individuals. Commonly, this species can be found in oligotrophic waters poor in electrolytes (Krammer 2000).

Midwest region records: pioneer reference.

Occurence in the samples: BRAZIL. Goís. Parque Nacional da Chapada dos Veadeiros, Córrego Estiva, A.A. França 22 (UFG 50 264); Córrego Estiva, A.A. França 21 (UFG 50 263).

\section{Pinnularia sp. 1}

Figure 39

The valves are elliptic-lanceolate; apices are rounded slightly cuneate; raphe is straight with distal ends deflected to the same direction; central area slightly rhombic and asymmetric, formed by shortening of the striae in the center; striae are widely spaced, slightly radiate and shorter towards the center. Apical axis: $61.59 \mu \mathrm{m}$; transapical axis: $10.1 \mu \mathrm{m}$; rate apical axis/transapical: $6.09 \mu \mathrm{m}$; 10 striae in $10 \mu \mathrm{m}$.

Occurence in the samples: BRAZIL. Goiás. Parque Estadual de Terra Ronca, Córrego Lapa, A.A. França 24 (UFG 50 266).

\section{Pinnularia sp. 2}

Figures 40-41

The valves are lanceolate; apices are rounded and slightly cuneate; raphe is filiform slightly undulate with distal ends in hook shape; central area is slightly rounded in one side of the valve and a small siliceous space in the center; striae are shorter in an irregular form, slightly radiate to convergent on the apices. Apical axis: 48.67-54.33 $\mu \mathrm{m}$; transapical axis: 9.7-9.92 $\mu \mathrm{m}$; rate apical axis/transapical: 4.90-5.60 $\mu \mathrm{m}$; 11 striae in $10 \mu \mathrm{m}$.

Occurence in the samples: BRAZIL. GoiÁs. Parque Nacional da Chapada dos Veadeiros, A.A. França 21 (UFG 50 263).

\section{Pinnularia sp. 3}

Figures 42-43

The valves are linear-lanceolate; apices are rounded to slightly cuneate; raphe is filiform; central area is asymmetric with a slightly siliceous spacing; striae are shorter and slightly radiate. Apical axis: $73.18 \mu \mathrm{m}$; transapical axis: $10.92 \mu \mathrm{m}$; rate apical axis/ transapical: $6.70 \mu \mathrm{m} ; 12$ striae in $10 \mu \mathrm{m}$.

Occurence in the samples: BRAZIL. Goiśs. Parque Nacional da Chapada dos Veadeiros, A.A. França (UFG 50 264).

\section{Pinnularia sp. 4}

Figura 44

The valves are linear; apices are rostrate to cuneate; raphe is straight with distal ends in bayonet shape and deflected to the same side; central area is asymmetric formed by a slightly shortening of the striae in the center; striae are radiate in the center and slightly convergent on the apices. Apical axis: $47.39 \mu \mathrm{m}$; transapical axis: $9.39 \mu \mathrm{m}$; rate apical axis/ transapical: $5.04 \mu \mathrm{m}$; 11 striae in $10 \mu \mathrm{m}$.

Occurence in the samples: BRAZIL. GoiÁs. Parque Nacional de Brasília, A.A. França 11 (UFG 50 253).

\section{Pinnularia sp. 5}

Figures 14-15

The valves are linear to elliptic-lanceolate and weakly convex; the apices are conic and does not differentiated; raphe is filiform; central area is rounded developed in a fascia that can appear in one side or both sides; striae are weakly radiate in the middle region turning into weakly convergent towards to the apices. Apical axis: 28.82-34.92 $\mu \mathrm{m}$; transapical axis: 5.51-5.95 $\mu \mathrm{m}$; rate apical axis/transapical: 4.96-6.06 $\mu \mathrm{m}$; $12-13$ striae in $10 \mu \mathrm{m}$.

The illustrated individuals on this study shown similarity with Pinnularia castraregina on the 
raphe, valve morphologic and apices as the species type, however, there is a slightly difference on the transapical axis and striation, which is described on the species type by Krammer (2000) are 7.5-8.9 $\mu \mathrm{m}$ and 9-10 striae in $10 \mu \mathrm{m}$.

Occurence in the samples: BRAZIL. GoIÁs: Parque Nacional de Brasília, Córrego Bananal, A.A. França 7 (UFG 50 252); Córrego Bananal, A.A. França 7 (UFG 50 253).

\section{Pinnularia sp. 6}

Figure 20

The valves are linear lanceolate with slightly undulate margins; apices are capitate to slightly rostrate; raphe is slightly undulate with slightly deflected distal ends; the middle region of the valve has a slight inflation; central area is rhombic widening to a small siliceous fascia; striae are radiate. Apical axis: 72.4-76.91 $\mu \mathrm{m}$; transapical axis: $12.32-13.25 \mu \mathrm{m}$; rate apical axis/transapical: $5.50-6.24 \mu \mathrm{m} ; 11-12$ striae in $10 \mu \mathrm{m}$.

The illustrated individuals on this study shown similarity with $P$. divergens var. protracta, however the transapical axis and the number of striae are smaller than the presented by Krammer \& Metzeltin (1998) for this species (16-6,8 $\mu \mathrm{m}$ and 9 striae in 10 $\mu \mathrm{m})$.

Occurence in the samples: BRAZIL. GoIÁs: Parque Nacional da Chapada dos Veadeiros, Córrego 1, A.A. França 7 (UFG 50 249); Córrego 1, A.A. França 4 (UFG 50 246); Córrego 1, A.A. França 6 (UFG 50 248).

\section{Acknowledgments}

The authors thank the National Council for Scientific and Technological Development (CNPq) for financial support (Award numbers 563134/2010-0 and 457431/2012-1); the Chico Mendes Institute for Biodiversity Conservation (ICMBio) for support in the Brasília National Park and in the Chapada dos Veadeiros National Park; the Environment and Water Resources Secretary (SEMARH) of the State of Goiás for support in the Terra Ronca State Park; the Laboratory of Ecology of the Federal University of Goiás (UFG) and the Laboratory of Periphyton of the Research Center for Limnology, Ichthyology and
Aquaculture (NUPELIA) of the State University of Maringa (UEM) for logistic support; the Coordination for the Improvement of Higher Education Personnel (CAPES) for the scholarship granted to AAF and BD. The authors also appreciate all their colleagues' help involved in the fieldwork and the anonymous reviewers.

\section{Literature cited}

Cattaneo, A., Kerimian, T., Roberg, M. \& Marty, J. 1997. Periphyton distribution and abundance on substrata of different size along a gradient of stream trophy. Hydrobiologia 354: 101-110.

Delgado, S.M. \& Souza, M.G.M. 2007. Diatomoflórula perifítica do rio Descoberto - DF e GO, Brasil, Naviculales (Bacillariophyceae): Diploneidineae e Sellaphorineae. Acta Botanica Brasilica 21: 767-776.

Guiry, M.D. \& Guiry, G.M. 2016. AlgaeBase. Worldwide electronic publication, National University of Ireland, Galway. Available in http://www.algaebase. org, searched (access in 29-VI-2016.

Hustedt, F. 1965. Neue und wenig bekannte Diatomeen: IX. Süsswaserdiatomeen aus Brasilien, inbesondre des Amazonasgebietes. Internationale Revue der gesamten Hydrobiologie und Hydrographie 50: 391-410.

Krammer, K. 1992. Pinnularia, eine Monographie der europäischen Taxa. Bibliotheca Diatomologica, Stuttgart, v. 26.

Krammer, K. 2000. The genus Pinnularia. Diatoms of Europe 1. Koeltz Scientific Books, Königstein, v. 1.

Law, R.J., Elliott, J.A. \& Thackeray, S.J. 2014. Do functional or morphological classifications explain stream phytobenthic community assemblages? Diatom Research (no prelo).

Menezes, M., Bicudo, C.E.M. \& Moura, C.W.N. 2015. Update of the Brazilian floristic list of Algae and Cyanobacteria. Rodriguésia 66: 1047-1062. 2015.

Metzeltin, D. \& Lange-Bertalot, H. 1998. Tropical Diatoms of South America I. Iconographia Diatomologica. Koeltz Scientific Books, Königstein, v.5.

Metzeltin, D. \& Lange-Bertalot, H. 2007. Tropical Diatoms of the South America II. Iconographia Diatomologica. Koeltz Scientific Books, Königstein, v.18.

Moreira-Filho, H. \& Valente-Moreira, I.M. 1981. Avaliação taxonômica e ecológica das diatomáceas (Bacillariophyceae) epífitas em algas pluricelulares obtidas nos litorais dos estados do Paraná, Santa Catarina e São Paulo. Boletim museu botânico municipal 47:1-17. 
Moro, R.S. \& Fürstenberger, C.B. 1997. Catálogo dos principais parâmetros ecológicos de diatomáceas nãomarinhas. Editora UEPG, Ponta Grossa.

Passy, S.I. 2007. Community analysis in stream biological monitoring: what must we measure and what we don't. Environmental Monitoring and Assessment 127: 409-417.

Pereira, A.C., Torgan, L.C. \& Melo, S. 2012. Pinnularia (Bacillariophyta) do curso inferior do rio Negro, Amazonas, Brasil: taxonomia e distribuição temporal. Acta Amazonica 42: 305-324.

Pereira, A.C., Torgan, L.C. \& Melo, S. 2013. Pinnularia Ehrenberg (Bacillariophyceae) de um lago de inundação amazônico (lago Tupé, Amazonas, Brasil). Iheringia, Série Botânica 68: 91-101.

Pereira, A.C., Torgan, L.C. \& Melo, S. 2014. Four new Pinnularia Ehrenberg (Bacillariophyta, Pinnulariaceae) species from Amazonian black water (Tupé Lake, Amazonas State, Brazil). Phytotaxa 158: 154-168.

Brassac, N.M. \& Ludwig, T.A.V. 2006. Diatomáceas da Bacia do rio Iguaçu, Paraná, Brasil: Pinnularia e Caloneis. Hoehnea 33: 127-142.

Rocha, A.C.R. \& Bicudo, C.E. 2008. Criptógamos do Parque Estadual das Fontes do Ipiranga, São Paulo, SP. Algas,25: Bacillariophyceae (Naviculales: Pinnulariaceae). Hoehnea 35: 597-618.

Round, F.E., Crawford, R.M. \& Mann, D.G. 1990. The Diatoms: biology and morphology of the genera. Cambridge University Press, Cambridge.
Silva, F.A.M., Assad, E.D. \& Evangelista, B.A. 2008. Caracterização climática do bioma Cerrado. In: S.M. Sano, S.M.P. Almeida \& J.F. Ribeiro (eds.). Cerrado: Ecologia e Flora. Embrapa Informação Tecnológica, Brasília, pp. 69-87.

Silva, W.J., Nogueira, I.S. \& Souza, M.G.M. 2011. Catálogo de diatomáceas da região Centro-Oeste brasileira. Iheringia 66:61-86.

Silva, W.J., Ruwer, D., Nogueira, I.S., Dunck, B. 2016. The genus Pinnularia (Bacillariophyta, Pinnulariaceae) from Lago dos Tigres, Britânia, Goiás, Brazil. Biota Neotropica 16: e20150028.

Simonsen, R. 1974. The diatom plankton of the indian ocean expedition of R/V "Meteor". Meteor Forschungsergebnisse reihe D-Biologie 19:1-66.

Souza, M.G.M \& Moreira-Filho, H. 1999. Diatoms (Bacillariophyceae) of two aquatic macrophyte banks from Lagoa Bonita, Distrito Federal, Brazil, II: Navicula sensu lato and Pinnularia Bull. Plantenium Belg. 67: 279-288.

Stevenson, R.J. 1997. An introduction to algae ecology in freshwater benthic habitats. In: R.J. Stevenson, M.L. Bothwell \& R.L. Lowe (eds.). Algal ecology in freshwater benthic ecosystems. Academic Press, San Diego, pp. 3-30.

Tremarin, P.I., Moreira-Filho, H. \& Ludwig, T.A.V. 2010. Pinnulariaceae (Bacillariophyceae) do rio Guaraguaçu bacia hidrográfica litorânea paraense, Brasil. Acta Botanica Brasilica 24: 335-353. 